UDC $81 ' 271+316.76: 005.336 .2$

DOI https://doi.org/10.32841/2409-1154.2021.47-2.30

Tarnavska T.V., Ph.D. in Pedagogy, Associate Professor, Associate Professor at the Department of Foreign Languages for Mathematical Faculties Taras Shevchenko National University of Kyiv

\author{
Glushanytsia N. V., \\ Ph.D. in Pedagogy, Associate Professor, \\ Associate Professor at the Department of Foreign Languages and Applied Linguistics \\ National Aviation University
}

\title{
SECONDARY LINGUISTIC IDENTITY IN THE CONTEXT OF INTERCULTURAL COMMUNICATION
}

Summary. Secondary linguistic identity is a linguodidactic category thatmeans a person's ability to effectively communicate in a foreign language. The development of secondary linguistic identity is the intended goal of a foreign language training. English learning is a cognitive and creative process. The development of a secondary linguistic identity implies students mastering the verbal code of a foreign language and their ability to put it into practice. A native speaker's inherent picture of the world is to be created in the student's mindset. The basic prerequisite for establishing full mutual understanding between people across various cultures is the students' ability to find themselves in the dimensions of two different sociocultural communities and feel the difference between them. The foreign language training assumes the development of interconnected and interdependent personal qualities which are considered as a system that operates as a whole to provide the single focused result.

Foreign language training in pragmatic or practical, cognitive and general educational aspects is a necessary condition for an effective process of the foreign language communicative competence development, because the intended result of this process is a specialist capable of successful foreign language professional communication at the intercultural level.

Students need to think as much as possible in a language they learn. Unplanned use of the language is efficient for thinking. Target language thinking improves language ability. There are definite benefits from making an effort to think through the target language. Development of the secondary linguistic identity is based on communicative, competency, cultural, systemic, and the Foreign Language Across the Curriculum approaches. The dominant ones are the communicative and cultural approaches. The article identifies the ways of secondary linguistic identity development. A number of communicative oriented exercises, which involve much more than just drilling and memorizing and provide the learners' ability to effectively communicate in a target language are suggested.

Key words: secondary linguistic identity, thinking in English, communicative activities, communicative language teaching, intercultural communicative competence.

Introduction. The methodology of teaching a foreign language as a science operates in such categories as "communicative competence", "speech ability", "social factors of communication", etc., which are reflected in the development of learning technologies with a pronounced communicative orientation. Secondary linguistic identity is a linguodidactic category that means a person's ability to effectively communicate in a foreign language. The development of secondary linguistic identity is the intended goal of a foreign language training. Aviation English learning is a cognitive and creative process. The development of a secondary linguistic identity implies students mastering the verbal code of a foreign language and their ability to put it into practice. A native speaker's inherent picture of the world is to be created in the student's mind-set.

Students have to constantly find themselves in the dimensions of two different socio-cultural communities and feel the difference between them. That is a basic prerequisite for establishing full mutual understanding between people across various cultures.

The development of the secondary linguistic identity traits should meet the professionally related interests and needs. Therefore, students must be able to carry out textual activities in the language they are learning. Textual activity is different from speaking behaviour where language clichés in certain situations are used. Such kind of speaking only creates the illusion of communication and has nothing to do with "creative" language, which is the result of textual activity. In our opinion, in order to develop students' ability to be creative, they should be given the opportunity to realize their personal communicative intentions.

Based on the above, the process of learning a foreign language is the progression of their personal development and the development of their social qualities.

We consider foreign language training in pragmatic or practical, cognitive and general educational aspects, which is a necessary condition for an effective process of the foreign language communicative competence (FLCC) development, because the intended result of this process is a specialist capable of successful foreign language professional communication at the intercultural level.

Along with the development of ability to intercultural communication, the foreign language training assumes the development of personal qualities such as intelligence, attention, memory, interest in educational and cognitive activities, the ability to see, understand and accept common and different in the national cultures, the ability to social interaction, willingness to use a foreign language as a means of communication, and tolerance. All these aspects are interconnected, interdependent. Underestimation or overestimation of any of them can negatively affect the quality of communication and interaction skills. This system operates as a whole to provide the single focused result. 
Oral and written communication is realized in four types of speech activity: speaking, listening, reading and writing. The training of these activities should be carried out in close connection, but with a differentiated approach to each of them. In the learning process, speaking should take place simultaneously with the formation of comprehension skills of written or audio text and, conversely, after reading or listening to the text, students should be able to express their opinion (orally or in writing) about the content. Oral messages may be accompanied by taking notes.

Literature review. The findings of the Y.Y.C. Ho's [1] study "implied that Communicative Language Teaching (CLT) facilitates students' English learning, raises their confidence, and enhances their communicative competence". E.M. Shinta and A. Triastuti [2], emphasize that according to the CLT principles, the content of learning materials is to be a close simulation of the real-life situations. Language training is focused on involving second language learners to purposeful classroom activities in which learners use and reproduce language as it is used in real communication beyond the classroom in meaningful situations [3].

The Communicative Language Teaching method is realized through learning about the target language's culture by reading short stories and fables instead of simplified novels [4], repetitive listening, which is considered as cognitively beneficial and has a significant impact on listening comprehension [5]. Podcasts are another popular and motivating technological tool for developing listening skill [6].

Methods of foreign language teaching and learning assume that learners need to think as much as possible in a language they learn. Unplanned use of the language is efficient for thinking. Target language thinking improves language ability. There are definite benefits from making an effort to think through the target language [7].

It is thought that "operating effectively across boundaries is more complex than traditional essentialist models in cross-cultural studies suggest". J. Kassis-Henderson, L. Cohen and R. McCulloch [8] present a teaching model that moves away from static comparative models of intercultural interaction and teaches students to learn to realize the multiple aspects of their own and others' identities. The model helps students develop a mind-set to cope with the difficulties facing today's professionals.

Telecollaboration, as the use of online communication tools, provides virtual interaction between people of different cultural backgrounds enabling learners to get involved in thought-provoking conversations, practice their language and results in intercultural communicative competence development $[9 ; 10 ; 11 ; 12]$. Telecollaboration can act as a catalyst for promoting language skills development, intercultural communicative competence (ICC), and multiple literacies [13].

The aim of the article is to identify the ways of secondary linguistic identity development. To achieve the aim, we suggested a number of exercises providing the learners' ability to effectively communicate in a foreign language.

Findings and discussion. Development of the secondary linguistic identity is based on communicative, competency, cultural, systemic, and the Foreign Language Across the Curriculum (FLAC) approaches. The dominant ones are the communicative and cultural approaches.

To reach the intended result, a number of communicative oriented exercises which involve much more than just drilling and memorizing, has been systemized.

1. Short stories for reading, listening, enriching vocabulary, and discussing.

One of the examples is Paulo Coelho's "The story of the pencil". Students read and listen to how the author compares us with a pencil. They discuss how much we can learn about having a positive approach towards life and realizing we are capable of incredible things. After the discussion, they are suggested thinking of something other than a pencil they can compare themselves with. Students have always been inspired and very creative while telling their own stories. This is an efficient way to develop communicative skills.

2. The fable "Porcupine \& the Snakes" can be an example of retelling the story from different points of view.

"A Porcupine was looking for a good home. At last he found a little sheltered cave, where lived a family of Snakes. He asked them to let him share the cave with them, and the Snakes kindly

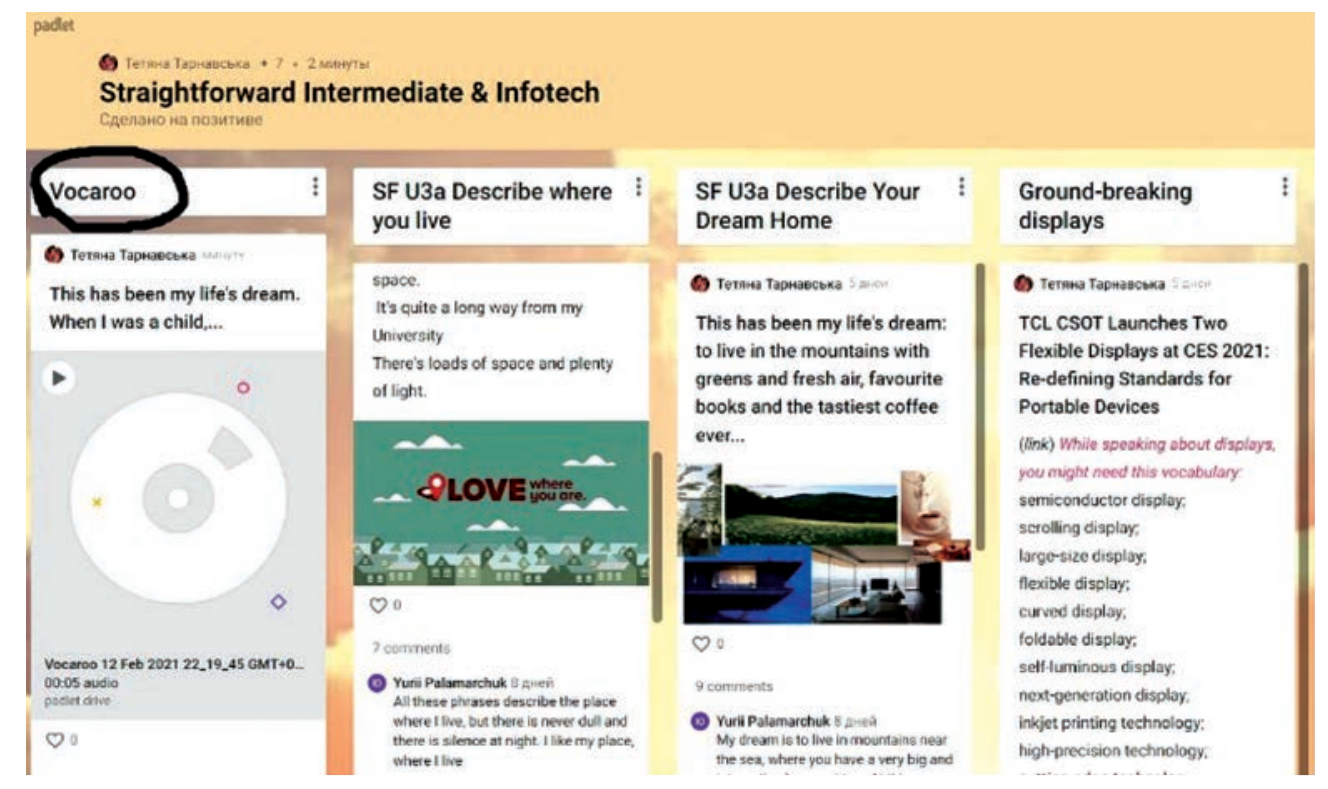

Fig. 1. Using Padlet and Vocaroo 
consented. The Snakes soon wished they had not given him permission to stay. His sharp quills pricked them at every turn, and at last they politely asked him to leave. "I am very well satisfied, thank you," said the Porcupine. "I intend to stay right here." And with that, he politely escorted the Snakes out of doors. And to save their skins, the Snakes had to look for another home".

Students retell the story from the view of the Porcupine and the Snakes. They explain the meaning of the saying "Give a finger and lose a hand" and think of their own examples.

3. A great number of communicative activities can be done in Padlet. To improve student's speaking, listening and networking skills we use it with Vocaroo voice recorder. Students are provided with the beginning of the story in the Padlet. One by one they listen, record their own 2 or 3 sentences to continue the story and add it as a next post.

4. One of the students' favourite activities is so called "Thinking in English". They watch a short video with no sound and describe what is happening on the screen. While doing this exercise, students realize the lack of the simplest every day vocabulary. It motivates them to describe in thoughts everything that happens around, and search the needed words in English.

To let students feel the difference between the verb tenses, every single lesson should contain an exercise like putting the verb into different tenses according to the different time expressions. Learning the verb tenses via comparison is the best way to learn how to use them correctly to avoid misunderstanding and miscommunication (fig. 2).

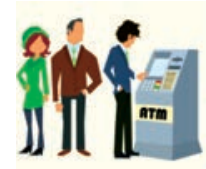

\section{He (withdraw) some money...}

... yesterday to buy a car but it wasn't enough. ... for his daughter but he is not sure he will do it today.

... When he noticed that someone was looking over his shoulder.

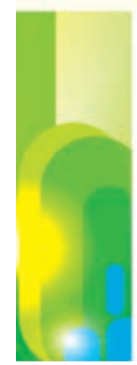

(not) ... every day, he usually ... once a week. ... for 10 minutes so people in the line are getting nervous.

... so we can go somewhere for a drink.

... and bought some fruit in the street market.

... by the time we come.

... before he left the bank branch.

... tonight because he promised to lend me some.

... if you really need it.

Fig. 2. Learning the verb tenses via comparison

For this purpose, comparing English grammar structures with their equivalent in the first language is meaningful. Furthermore, they are designed to teach the sentence as a structural, grammatical element of the language, rather than utterance as it is used in the performance of acts of communication. Class activities are to be structured to emphasize "purposeful" communicative language use, i. e., where sender and receiver interact to accomplish a mutually defined goal or objective.

Using original English materials instead of "artificial language" of student books will also provide learning English as it is spoken by native speakers. One of the examples is the A.J. Hoge's [14] approach to teaching English that offers not to focus on learning grammar but just listen and read English materials as often as you can. Traditional methods of learning English assume learning the rules, which results in taking a lot of time to choose the correct tense to say something. A.J. Hoge suggests learning a language like the kid do. They just hear the same kinds of sentences and don't think about grammar. A.J. Hoge recommends listening to short stories several times during a week or even a month until you are sure you understand every single word and the whole meaning of the text. This way to learn grammar has been brought into our practice and proved as one of the most of natural ways to learn how to think in English instead of thinking about grammar patterns.

C. Azevedo's [15] "blog for movie segments to enhance topic based classes, focusing on conversation, listening comprehension and vocabulary acquisition" is one more example of inspiring and highly motivating language learning. It includes a number of movie segments and activities to practice grammar through fun, challenging exercises. It also contains the tips to develop your own grammar activities.

Conclusions. Secondary linguistic identity, as a linguodidactic category, is a kind of personality able to think in the target language. Therefore, the language learning is to be as close as possible to reallife communication. We identified the ways of secondary linguistic identity development. suggested a number of exercises providing the learners' ability to effectively communicate in a foreign language. Thus, secondary linguistic identity is the ability to master the verbal-semantic code of the target language. Its components are presented as the set of competencies needed for the efficient intercultural communication.

\section{References:}

1. Ho Y.Y.C. Communicative language teaching and English as a foreign language undergraduates' communicative competence in Tourism English. Journal of Hospitality, Leisure, Sport \& Tourism Education. 2020. Vol. 27. URL: https://doi.org/10.1016/j.jhlste.2020.100271.

2. Shinta E.M., Triastuti A. Communicative language teaching and its application in developing slow learners' 21st century skills. Teacher Education and Professional Development in Industry 4.0 : Proceedings of the 4th International Conference on Teacher Education and Professional Development (InCoTEPD 2019), Yogyakarta, Indonesia, 13-14 November 2019. Boca Raton : CRC Press, 2020. P. 260-270.

3. Farid A. Communicative Language Teaching: Implications for The Communicative Classroom. Educate. 2017. Vol. 4(1). P. 47-56.

4. Engwers A. "In that case I choose to work with short stories": A study about how English short stories are taught by nine upper secondary school teachers in Sweden and said teachers' attitudes towards short stories. URL: http://mdh.diva-portal.org/smash/record.jsf?pid=diva2 $\% 3 \mathrm{~A} 1526270 \&$ dswid $=-695$.

5. S Sendağ S., Gedik N., Toker S. Impact of repetitive listening, listeningaid and podcast length on EFL podcast listening. Computers \& Education. 2018. Vol. 125. P. 273-283.

6. Indahsari D. Using podcast for EFL students in language learning. JEES (Journal of English Educators Society). 2020. Vol. 5(2). P. 103-108.

7. Cohen A.D. In which language do/should multilinguals think? Language, Culture and Curriculum. 1995. Vol. 8. Iss. 2. P. 99-113. DOI: 10.1080/07908319509525194.

8. Kassis-Henderson J., Cohen L., McCulloch R. Boundary crossing and reflexivity: Navigating the complexity of cultural and linguistic identity. Business and Professional Communication Quarterly. 2018. Vol. 81(3). P. 304-327. URL: https://doi. org/10.1177/2329490618784893.

9. Orsini-Jones M., Lee F. Intercultural Communicative Competence for Global Citizenship: Identifying cyberpragmatic rules of engagement in telecollaboration. Berlin : Springer, 2018. 200 p.

10. O'Dowd R., Dooly M. Intercultural communicative competence development through telecollaboration and virtual exchange. The Routledge Handbook of Language and Intercultural Communication. London : Routledge, 2020. P. 15-30. 
11. Lee L. Using telecollaboration 2.0 to build intercultural communicative competence: a Spanish-American exchange. Language Learning and Literacy: Breakthroughs in Research and Practice : in 2 vol. Hershey, PA : IGI Global, 2020. Vol. 2. P. 575-593. DOI: 10.4018/978-15225-9618-9.ch030.

12. Toscu S., Erten I.H. Developing intercultural communicative competence by the means of telecollaboration. Educ Inf Technol. 2020. Vol. 25. P. 4517-4534. URL: https://doi.org/10.1007/ s10639-020-10174-8.

13. Avgousti M.I. Intercultural communicative competence and online exchanges: a systematic review. Computer Assisted Language Learning. 2018. Vol. 31. Iss. 8. P. 819-853. DOI: $10.1080 / 09588221.2018 .1455713$.

14. Learn With Your Ears, Not Your Eyes. Effortless English Page : Fan website about method of learning English by A.J. Hoge. URL: https://cutt.ly/dlqtiha.

15. Movie Segments to Assess Grammar Goals. URL: https://cutt.ly/tlqwz0k.

Тарнавська Т. В., Глушаниця Н. В. Вторинна лінгвістична ідентичність у контексті міжкультурної комунікації

Анотація. Лінгводидактична категорія «вторинна лінгвістична ідентичність» - це здатність людини до ефективного іншомовного міжкультурного спілкування. Навчання іноземної мови являє собою свідомий (когнітивний) і творчий процес, а не запрограмовану поведінку. Процес становлення вторинної лінгвістичної ідентичності пов'язаний $з$ оволодінням студентами вербальним кодом іноземної мови, набуттям уміння застосовувати його на практиці, а також із формуванням у їхній свідомості «картини світу», притаманної носію певної мови. Студенти мають відчувати себе у вимірах двох соціокультурних спільнот та чітко усвідомлювати різницю між ними. Тільки за цієї умови можливе встановлення цілковитого розуміння між представниками різних культур.

Ми розглядаємо навчання іноземної мови у прагматичному, когнітивному та загальноосвітньому аспектах, що
$€$ необхідною умовою ефективного процесу формування рис вторинної лінгвістичної ідентичності, оскільки результатом зазначеного процесу має бути фахівець, здатний здійснювати успішне професійне спілкування засобами іноземної мови на міжкультурному рівні.

Навчання іноземної мови, на нашу думку, є поняттям інтегративним, складниками якого є розвиток особистісних якостей (зокрема, інтелекту, уваги, пам'яті), формування інтересу до навчально-пізнавальної діяльності, здатності бачити, розуміти та приймати спільне й відмінне в різних національних культурах, формування готовності використовувати іноземну мову як засіб спілкування, толерантність. Навчання іноземної мови передбачає розвиток зазначених взаємопов'язаних і взаємозалежних особистісних якостей, що є системою, яка діє як ціле, щоб забезпечити єдиний цілеспрямований результат.

Розвиток вторинної лінгвістичної ідентичності базується на комунікативному, компетентнісному, культурному й системному підходах. Домінуючими є комунікативний і культурний підходи. У статті визначено шляхи розвитку вторинної лінгвістичної ідентичності. Запропоновано низку комунікативно орієнтованих вправ, які передбачають набагато більше, ніж просто зазубрювання та запам'ятовування, і забезпечують здатність учнів до ефективного спілкування. Метод комунікативного викладання мови реалізується через вивчення культури цільової мови шляхом читання коротких оповідань і байок замість адаптованих літературних творів, а також через багаторазове прослуховування текстів, що ефективно впливає на розвиток уміння сприймати інформацію іноземною мовою на слух. Одним із популярних і спонукальних технологічних інструментів для розвитку навичок аудіювання $є$ подкасти. Ефективним методом навчання студентів вільно спілкуватися іноземною мовою є спонтанне мовлення, що сприяє розвитку вміння думати мовою, яку вони вивчають.

Ключові слова: вторинна лінгвістична ідентичність, комунікативний підхід, мовна компетентність, комунікативні вправи, спонтанне мовлення. 